\title{
Intensifying forage legume strata system technology through dairy cattle production
}

\author{
Marcos E. Bollido \\ Northwest Samar State University, Calbayog, Philippines, markbollido@yahoo.com \\ Teresa B. Polbos \\ Northwest Samar State University, Calbayog, Philippines, teresapolbos@yahoo.com
}

See next page for additional authors

Follow this and additional works at: https://scholarhub.ui.ac.id/ajce

Part of the Animal Studies Commons, Food Security Commons, and the Income Distribution Commons

\section{Recommended Citation}

Bollido, Marcos E.; Polbos, Teresa B.; and Bejar, Feleciano R. (2020). Intensifying forage legume strata system technology through dairy cattle production. ASEAN Journal of Community Engagement, 4(1). Available at: https://doi.org/10.7454/ajce.v4i1.1084

Creative Commons License

(c) (i) ()

This work is licensed under a Creative Commons Attribution-Share Alike 4.0 License.

This Research Article is brought to you for free and open access by the Universitas Indonesia at ASEAN Journal of Community Engagement. It has been accepted for inclusion in ASEAN Journal of Community Engagement. 


\title{
Intensifying forage legume strata system technology through dairy cattle production
}

\author{
Marcos E. Bollidoa*, Teresa B. Polbos ${ }^{a}$, Feleciano R. Bejara \\ $a_{\text {Northwest Samar State University, Philippine }}$
}

Received: April 22nd, 2020 || Revised: July $7^{\text {th }}, 2020$ || Accepted: July 29th, 2020

\begin{abstract}
Intensification of forage legume strata system technology (FLSST) through dairy cattle production was implemented in collaboration with the Department of Agriculture and the local government unit of San Jorge, Samar, Republic of the Philippines. The beneficiaries of the program were selected based on specific criteria and qualifications. Farmers were given training on dairy cattle production, and 10 beneficiaries in five communities received one ready-to-breed cow. Each farmer-beneficiary established a $500 \mathrm{sqm}$ pasture area using FLSST. Abundant grasses and leguminous forages helped improve the health of the cattle. Cattle weighing an average of $150 \mathrm{~kg}$ grew to an average weight of $300 \mathrm{~kg}$. The cows gave calves through artificial insemination. Evident impacts were observed as follows: Ground-Level Impact: Participants appreciated the transformation of their idle land into productive land, and farmers were motivated to purchase additional ruminants. Five hectares of idle land was utilized. Deep-Level Impact: Individuals developed a positive attitude toward venturing into ruminant production. Attitudinal transformation among family members was valued by the community, especially by the five farmer-adopters of FLSST. External-Level Impact: Nonparticipants of the project planted leguminous forages in their idle land and developed a positive outlook toward pasture development and dairy cattle production.
\end{abstract}

Keywords: dairy cattle; forages; legumes; strata system; technology.

\section{Introduction}

A project to build awareness among participants on the importance of ruminant development and planting of various types of grass and legume plant using Food Leguminus Strata (FLSST) technology was implemented by NwSSU-San Jorge Campus, in collaboration with the Department of Agriculture (DA) Region 8-Livestock Program. Effective agricultural and natural resource management can be achieved only if these components are developed together so that they synergistically influence the production of goods and ecosystem services required for food security and environmental health. The integration between agricultural biodiversity, soil and water conservation, and other components of natural resource management has its big contribution to the well-being and sustainable livelihoods of people and communities (German et al., 2006).

\footnotetext{
*Correspondence Author: markbollido@yahoo.com
} 
Marcos E. Bollido, Teresa B. Polbos, Feleciano R. Bejar | ASEAN Journal of Community Engagement | Volume 4, Number 1, 2020

FLSST refers to a system of planting leguminous species, such as ipil-ipil, kakawate/madre de cacao, rensoni, flemingia, and indigofera, side by side in rows and columns. Fodder-yielding tree species may be planted at intervals ranging from $60 \mathrm{~cm} \times$ $60 \mathrm{~cm}$ to $3 \mathrm{~m} \times 3 \mathrm{~m}$ to achieve high-quality fodder production. Suitable management practices may help improve sustainable fodder production throughout the year. Labor costs may increase in the case of a cut-and-carry module, but the losses generated by the trampling of grazing/browsing animals are minimized, which may increase the quality of forage production (Sarvade et al., 2019).

It is important to ensure that milk animals are provided with good quality diets to optimize production. Dairying offers women regular daily income vital to household protection and well-being in the home. The efficiency of milking animals is affected by the lack of quality and quantities of feed and food. Local cows produce an average of 1,5 liter per day in cross-breeded cows, versus 5-8 liters per day, requiring better feeding mainly concentrates that farmers cannot afford. However, by raising crossed cows, farmers' incomes can be increased to twofold. Because feed costs are the key factor in the agricultural production of livestock, an significant factor in future development projects would be the increased independence in the feed production. (Khan, Peters, \& Uddin, 2009).

In rehabilitating cattle production and preserving biodiversity in agricultural ecosystems, silvopastoral systems involving native trees and shrubs are instrumental. The integration of trees, fuel and domesticated livestock is a sustainable agroforestry process that involves high-density fodder planting for livestock production (Murgueitio et al., 2011).

Enhanced per-animal efficiency, developing adequate animal production systems and increasing effectiveness on feed resources are important for improved future productivity. Ruminant production systems have decreased productivity as compared to demand-driven, intensive and privately managed non-ruminant systems because they are mostly left over by small, resource poverty-intensive farmers. (Devendra, 2000).

The choices for the animals' shelter are different and are taken according to the available space and cattle group size. In general, the farms are equipped with a shelter, built with various materials, and the animals are raised in one or more groups. Cultivators with no cattle sheds tend to hold dairy livestock in chains while calves in a separate community are free. The beds that normally consist of sand or other soils are 
Marcos E. Bollido, Teresa B. Polbos, Feleciano R. Bejar | ASEAN Journal of Community Engagement | Volume 4, Number 1, 2020

not treated properly. We found, however, that the bedding in the barn was not properly treated and worked efficiently in all situations. As a result, dairy cattle are often submerged in the water, with adverse health effects and a detrimental effect on the consistency of their milk. (Rossignoli, Di Iacovo, Moruzzo, \& Scarpellini, 2015).

The largest variable costs for modern livestock production is supplementary feed. Additional feeding is needed, particularly during the gestation and/or lactation of mature animals, where the physiological demands of animals are higher than that of their forage. The period of the supplement can be extended by various gestation periods or livestock seasons (Muir et al., 2015).

The benefits derived from FLSST include higher grass yields, maximized land use, controlled transmission of diseases to sensitive foodstuff species, and increased soil fertility through drilling species' ability to fix nitrogen. Furthermore, legumes increase the overall feeding value of the forage available and prolong the ruminant cattle grazing time.

The creation of legume-based farming systems means that Australian agriculture is globally competitive. There is no political impetus for agriculture to take responsibility for the environmental effects off-site. The agricultural systems based on annual species are unsustainable due to a lack of balance between water and nitrogen supply and demand that leads to water or groundwater discharges of nitrogen (Ridley et al., 2004).

Many farmers install barbed wire free multi-strata or multifunctional fences. Some trees stand close to water sources on other farms. Livestock farmers are cattle grower; a small number of cattle are sold on the market and some produce milk and butter for family consumption. (MEMORIAL, 2010).

Grass legume technology is important to ensure that continuous livestock projects will contribute to economic development, alleviation of poverty and protection of the environment. Using participatory methods and enhanced integration between the beef and dairy production chains is recommended for overcoming the constant budget constraints of public research institutions and ensuring that the evolved grass-legum technology is compatible with current farm cultural, social and environmental conditions. (Valentim \& Andrade, 2004). The higher nutritive value and intake of legumes relative to grass in animal digestive system may be attributed to several factors, this may include: faster rate of particle breakdown, faster digestion in the rumen, more 
Marcos E. Bollido, Teresa B. Polbos, Feleciano R. Bejar | ASEAN Journal of Community Engagement | Volume 4, Number 1, 2020

non-ammonium nitrogen reaching the small intestine, and higher efficiency of energy utilization despite the lower efficiency of nitrogen utilization (Laidlaw \& Teuber, 2001).

Small-scale production of milk has been found to be important with the potential to alleviate poverty, food security, enhance family nutrition, and generate income and jobs. In order to improve the lifestyle of small households by enhancing dairy production in this region, however, the diseases, volatile market conditions, high prices of drugs, feed concentrates, and lack of IA were the key constraints which were restricted by smallscales householders. (Uddin et al., 2012).

The key restrictions on production include the choice of species, breeds and animal availability; feed facilities and better feeding systems; better training, training and health services for animals; animal manure management; and coordinated promotion and marketing. (Devendra, 2000). Feeding forage legumes to ruminant pastures may boost the efficiency of animals and reduce the animal's reliance on a single species to meet all of their nutritional needs. Individual animals that graze forage usually have limited efficiencies due to their actual intakes of energy (because structural fibers can decrease digestion and clearance from the rumen). (Waghorn \& Clark, 2004).

Increases in the size of a family have resulted in smaller plots of land for cultivation to accommodate each of the farmers in the family. Unfortunately, this practice has led to lower production and income among farmers. The kaingin farming system, which is widely practiced in Samar, causes land degradation. In this case, farmers abandon farm areas after several cropping seasons and the land eventually becomes idle. Grasscontrolled pastures are an interesting model for smallholders who would like to retain their land's recovery capacity, because for a couple of years, integrating livestock into grass-controlled pastures would not alter the fainting vegetation. (Hohnwald et al., 2006).

Farmers depend on their produce, which is often unable to meet the food needs of the family. Few farmers own livestock, especially cattle. Dairy cattle can be raised in the backyard if they are provided a shed and forage source. Because this animal requires only simple management, a farmer's wife (woman) or elder children can manage a dairy cattle project.

Specific farm sizes, intensification activities, and mechanization rates are subject to sustainable technologies and rely on local resources. Integrated systems (IS) combining animals and high-quality drilling can generate high productivity per unit area given that 
Marcos E. Bollido, Teresa B. Polbos, Feleciano R. Bejar | ASEAN Journal of Community Engagement | Volume 4, Number 1, 2020

the mineral nutrients needed are available and continuously refurbished from the beginning of production. Perennial species have many energy advantages over other species since they last for several years once formed (Hernández \& Sánchez, 2014).

Food and power sources combined with agricultural systems can be used and also regarded as a secure investment. When large concentration of animals is present, it is possible to extend land use to include lowland rainfed areas, uplands and even highlands. Improved crop production is a significant approach to growing and optimizing animal productivity. feed supply (Devendra, 1997).

The majority of nutrients in pastures on farms are from top-soil and their roots; mature forage resources help the fertility of soils by the supply of literally recycled nutrients. This finding indicates that the related nutrient stocks and the accumulation of drill mass are probably sustained mainly by the amounts of bovine excreta, dirt, organic matter and litter mineralization with little commercial fertilizer input (Rueda et al., 2020).

Tropical legumes contain the same amount of nitrogen as temperate. In herbaceous legumes in blends with grasses, the amount added to pasture systems can be between 30-290 kg / ha / yr and $575 \mathrm{~kg} / \mathrm{ha} / \mathrm{yr}$ for pure legume stand. The highest live-weight gain of livestock from cattle fed legumes (Lecture, 1997).

Devendra and Chantalakhana (2002) concluded that improved systems for livestock production would contribute significantly towards improved human health, rural development and poverty reduction. Such systems offer household benefits to several levels, including medium- and long-term savings, improved mixed farm system efficiency, sustainability of agricultural and environmental systems and social stability. Although big ruminants such as buffalo and cattly are valuable for agriculture and farm health, milk and beef, plowing and deer production are important for nutrition and household protection, small animals such as goats, sheep, chickens or pigs and ducks.

The drivers of intensification of milk production in smallholder farms have been established and the related changes at the farm and farming systems level quantified. Intensification calls for greater use of external services, including animal substitution, feeding facilities, animal welfare and breeding, and recognition for the help of the livestock and development populations (Bebea et al., 2003).

The use of the available forage and the projected suitability of any particular method to raise livestock and the resulting degree of use are always enough to provide a short- 
Marcos E. Bollido, Teresa B. Polbos, Feleciano R. Bejar | ASEAN Journal of Community Engagement | Volume 4, Number 1, 2020

term economic return to the sown forage by the livestock. The degree of utilization generally depends on the environmental quality, the duration of the growing and nongrowing seasons and the adaptation of plant species to the local climate. (Kemp \& Michalk, 2007).

The availability of grassland drilling in tropical systems is almost wholly dependent on animal feeding. During long stretches of drought in most agricultural regions every year, growth and drilling efficiency are drastically reduced. This decrease in the production of food biomass is the main cause of low livestock productivity in the tropics (Cardona et al., 2014).

\subsection{Objectives}

The general aim of the project is to increase farmers' income from dairy cattle production and utilization of idle land. The specific objectives of this project are as follows:

1. Develop pasture areas by adopting FLSST and utilize idle lands for dairy cattle feeds

2. Provide 10 heads of dairy cows to 10 families in 5 barangays

3. Increase farmers' income by $40 \%$ from the sale of calves and processed cow's milk

4. Increase the numbers of cattle and family beneficiaries by $50 \%$ every 2 years after project implementation

\section{Methods}

The project began with consultations between the DA and Local Government Unit (LGU) of San Jorge, Samar, Republic of the Philippines. The beneficiaries were selected from pre-listed barangays with an excellent track record in previous projects implemented by the DA according to a set of criteria and qualifications established by the University and DA Region 8. After beneficiary selection, training needs assessment and economic profiling were conducted to establish baseline data on the status of the farmer-beneficiaries, including the size of their idle land and existing forages, farm animals owned, and average family income, among others. A consultative meeting was conducted with the beneficiaries to discuss their roles and responsibilities and the various conditions of the project. After the consultative meeting with all stakeholders, drafting of the memorandum of agreement (MOA) followed. This MOA was signed by 
Marcos E. Bollido, Teresa B. Polbos, Feleciano R. Bejar | ASEAN Journal of Community Engagement | Volume 4, Number 1, 2020

the University, the DA, San Jorge LGU, barangay captains (or a barangay LGU representative), and farmer-beneficiaries.

\subsection{Strategy}

The strategy implemented in this research could be divided into 12 steps as follows:

1. Meet with DA-LGU San Jorge to discuss the project, plan for the implementation of the project, and select barangays and beneficiaries

2. Draft the MOA between the University, barangay, farmers, and DA

3. Sign the tripartite MOA, signed by the beneficiaries, Department of Agriculture and University

4. Conduct cornerstone training/values formation seminars

5. Conduct training on dairy cattle production

6. Conduct training on milking and milk processing

7. Construct cattle shed for individual farmers

8. Turn over dairy cattle to beneficiaries

9. Prepare the land of individual farmers for pasture development

10. Gather plant materials for individual farmers

11. Plant leguminous forages on farmers' land

12. Manage dairy cattle production

\subsection{Project sustainability}

Some of the terms and conditions that must be applied to sustain the project include:

1. The MOA must sign by the beneficiaries, partners, and University

2. Beneficiaries must establish a pasture area before the release of cattle

3. Beneficiaries must transfer one weaned calf to another qualified adopter

4. Beneficiaries must conduct regular deworming, vaccination, and animal treatment

5. The DA and University must closely and regularly monitor the project

6. The original beneficiary must transfer the mother cow to the next farmer beneficiary, including forage planting materials, after the first calf is weaned

7. Beneficiaries must immediately report to the University or DA-LGU San Jorge of any animal illness or any issue or problem related to the project 
Marcos E. Bollido, Teresa B. Polbos, Feleciano R. Bejar | ASEAN Journal of Community Engagement | Volume 4, Number 1, 2020

8. The progress of the project must be reported to the DA Region 8, Tacloban City, Republic of the Philippines

The results framework shown in Figure 1 represents the strategy of the project stakeholders (e.g., farmers, implementers, and DA) to achieve specific objectives. This tool was used to help stakeholders identify and focus on the key objectives of the project. It was also used as a basis for the impact evaluation of the project. Details of the inputs, activities, outputs, outcomes, and impacts of the framework were determined and agreed upon by all stakeholders.

The results framework was designed during the project identification phase and then improved and adapted throughout the project cycle. Prior to the development of a full-fledged results framework, the problem the project intended to solve was explained. The result framework was an idea on how the project inputs could lead to the desired outcomes and the knowledge and skills required of the beneficiaries and measured the progress and results of the project. The results framework is the result of careful planning, communications, and management that seeks to emphasize the intended results of key project objectives. A good results framework is based on good analysis, standard theories in the technical sector, and the expertise of on-the-ground implementers. Such a framework would lead to the identification of performance indicators and risks that may impede the attainment of the goal. 
Marcos E. Bollido, Teresa B. Polbos, Feleciano R. Bejar | ASEAN Journal of Community Engagement | Volume 4, Number 1, 2020

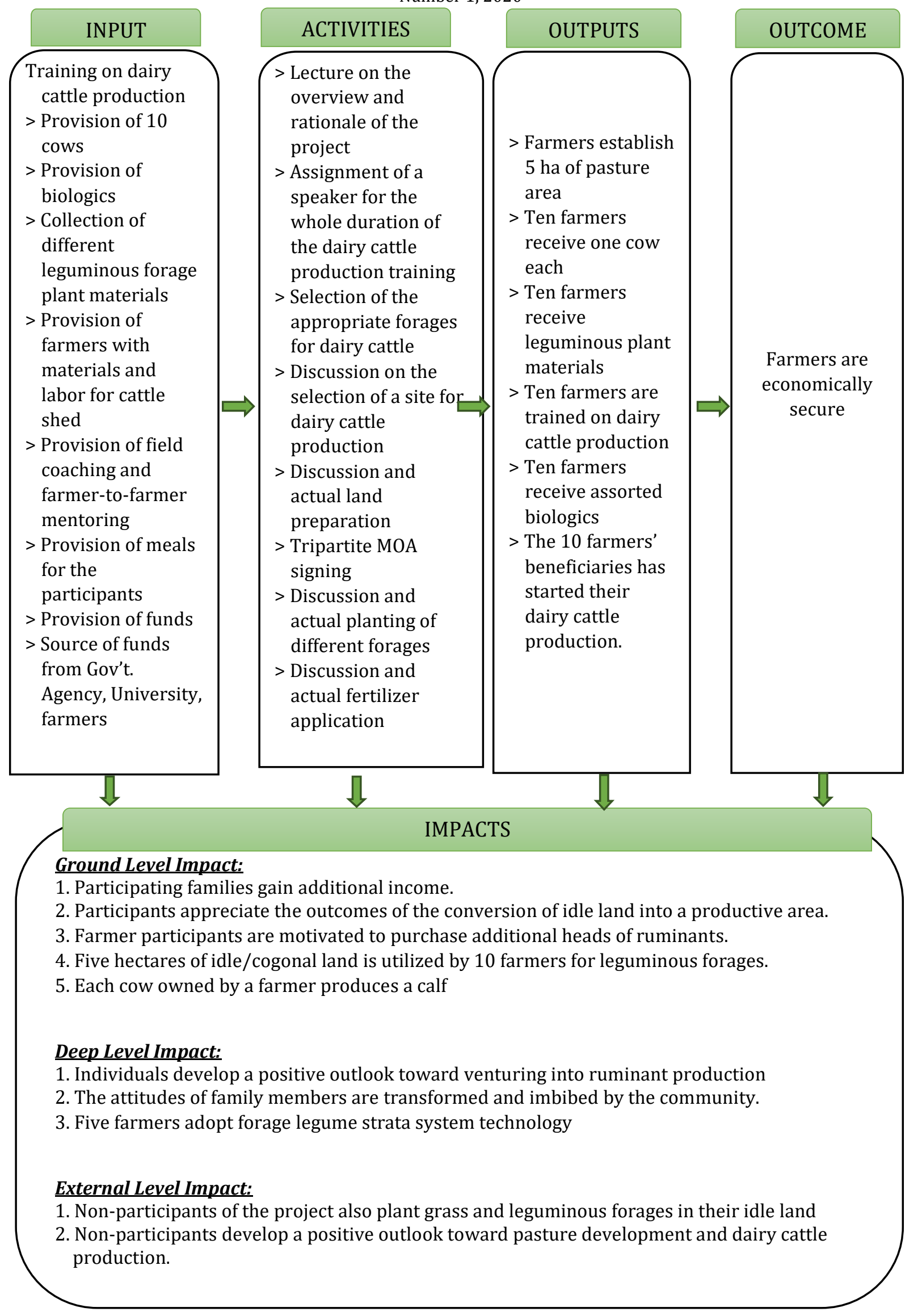

Fg. 1 Result Framework 
Marcos E. Bollido, Teresa B. Polbos, Feleciano R. Bejar | ASEAN Journal of Community Engagement | Volume 4, Number 1, 2020

Table 1. Monitoring and Evaluation Framework

\begin{tabular}{|c|c|c|c|c|c|}
\hline & Indicator & Baseline & Target & Data Source & Responsible \\
\hline ర్ల & $\begin{array}{l}\text { Increase farmers' } \\
\text { income from dairy } \\
\text { cattle production } \\
\text { as an alternative } \\
\text { livelihood }\end{array}$ & $\begin{array}{l}\text { PhP 3,000 } \\
\text { monthly } \\
\text { income }\end{array}$ & $\begin{array}{l}\text { PhP 5,000 monthly } \\
\text { income }\end{array}$ & $\begin{array}{l}\text { Computed } \\
\text { monthly } \\
\text { expenses and } \\
\text { income }\end{array}$ & $\begin{array}{l}\text { Project } \\
\text { proponent and } \\
\text { members }\end{array}$ \\
\hline 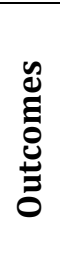 & $\begin{array}{l}\text { Farmers are } \\
\text { economically } \\
\text { secured }\end{array}$ & $\begin{array}{l}\text { Fewer than } 3 \\
\text { meals a day, } \\
\text { malnourished } \\
\text { children, } \\
\text { clothing is not } \\
\text { appropriate }\end{array}$ & $\begin{array}{l}\text { Meals } 3 \text { times a } \\
\text { day, children are } \\
\text { well-nourished } \\
\text { and with } \\
\text { appropriate } \\
\text { clothing }\end{array}$ & $\begin{array}{l}\text { Actual family } \\
\text { interviews and } \\
\text { secondary data }\end{array}$ & $\begin{array}{l}\text { Project } \\
\text { proponent and } \\
\text { members }\end{array}$ \\
\hline \multirow{4}{*}{ 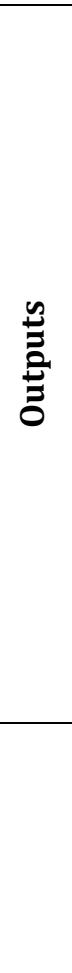 } & $\begin{array}{l}\text { Establish } 5 \text { ha. } \\
\text { pasture area }\end{array}$ & $\begin{array}{l}\text { No forage } \\
\text { plantations }\end{array}$ & $\begin{array}{l}5 \text { hectares } \\
\text { leguminous } \\
\text { forages planted by } \\
\text { the } 10 \\
\text { beneficiaries }\end{array}$ & $\begin{array}{l}\text { Actual farm } \\
\text { visits and } \\
\text { measurement } \\
\text { of the size of } \\
\text { farms planted } \\
\text { with forages } \\
\end{array}$ & $\begin{array}{l}\text { Project } \\
\text { proponent and } \\
\text { members }\end{array}$ \\
\hline & $\begin{array}{l}10 \text { farmers receive } \\
\text { cows, biologics, } \\
\text { and leguminous } \\
\text { plant materials }\end{array}$ & $\begin{array}{l}\text { Zero cattle in } \\
\text { the villages, no } \\
\text { leguminous } \\
\text { forage plant } \\
\text { materials }\end{array}$ & $\begin{array}{l}10 \text { heads dairy } \\
\text { cattle, biologics, } \\
\text { and forage } \\
\text { planting materials } \\
\text { distributed to } 10 \\
\text { farmers }\end{array}$ & $\begin{array}{l}\text { Actual farmer } \\
\text { visits and } \\
\text { numbers of } \\
\text { cattle, } \\
\text { biologics, and } \\
\text { plant materials }\end{array}$ & $\begin{array}{l}\text { Project } \\
\text { proponent and } \\
\text { members }\end{array}$ \\
\hline & $\begin{array}{l}10 \text { farmers are } \\
\text { trained on dairy } \\
\text { cattle production }\end{array}$ & $\begin{array}{l}\text { No training on } \\
\text { dairy cattle } \\
\text { production \& } \\
\text { values } \\
\text { formation }\end{array}$ & $\begin{array}{l}\text { Training on values } \\
\text { formation \& dairy } \\
\text { cattle production } \\
\text { conducted }\end{array}$ & $\begin{array}{l}\text { Actual } \\
\text { attendance of } \\
\text { the training } \\
\text { attendees }\end{array}$ & $\begin{array}{l}\text { Project } \\
\text { proponent and } \\
\text { members }\end{array}$ \\
\hline & $\begin{array}{l}10 \text { farmers' } \\
\text { beneficiaries } \\
\text { received dairy } \\
\text { cattle. }\end{array}$ & $\begin{array}{l}\text { Non-farmer } \\
\text { owned a dairy } \\
\text { cattle in the } \\
\text { community }\end{array}$ & $\begin{array}{l}10 \text { farmers owned } \\
1 \text { head ready-to- } \\
\text { breed dairy cattle }\end{array}$ & $\begin{array}{l}\text { Actual visit and } \\
\text { number of } \\
\text { farmers who } \\
\text { owned and } \\
\text { cared dairy } \\
\text { cattle }\end{array}$ & $\begin{array}{l}\text { Project } \\
\text { proponent and } \\
\text { members }\end{array}$ \\
\hline
\end{tabular}

Source: Authors (2019)

The monitoring and evaluation (M\&E) framework shown in Table 1 was used by the implementer to monitor and evaluate the project. Farmers were also oriented about this framework. Farmers could report their accomplishments and the success of the project based on the given baseline data and targets.

The M\&E framework provides a structured approach with advice on spatially explicit tools for hands-on tasks, such as cumulative project impact assessment. The practical steps to track and assess a project have been taken using proven mechanisms and approaches. (Stelzenmüller et al. 2013). Lamhauge et al. (2012) suggested that the 
Marcos E. Bollido, Teresa B. Polbos, Feleciano R. Bejar | ASEAN Journal of Community Engagement | Volume 4, Number 1, 2020

adaptation-specific or -related elements of M\&E systems used by policy and project collaboration agencies and programmes. In designing, collaborating projects and programmes, M\&E is an important component. This method ensures that the future benefits of interventions are recognized and can lead to the production of potential interventions. On this basis, it defines the $M \& E$ characteristics for the correct adjustment and shares lessons learned on the use and use of adaptation indicators.

Using the Monitoring and Evaluation Framework the beneficiaries were evaluated their process in dairy cattle production for a stable livelihood, eventually for a sustainable income. Documented their income derived from dairy cattle production, their pasture development based on the baseline data. Monitoring and evaluation were also conducted after the farmers received dairy cattle, biologics, and planting materials. Farmers/beneficiaries have managed their animals based on their learning from the training on cattle production which was they attended.

\section{Result and Discussion}

The NwSSU-San Jorge Campus coordinated with DA Region 8 and DA-LGU San Jorge to disperse 10 cows to select farmers from a neighboring barangay of the University. Beneficiaries were selected based on specific criteria and qualifications. Dairy cattle dispersal was implemented after the University approved the proposed project to disperse 10 heads of dairy cattle to farmer-beneficiaries who were the beneficiaries of the project implemented entitled Farmers Livestock School. Makori (2007) said the Farmers' Field (FFS) extension strategy was being applied to disseminate information and skills in relation to seed, soil and water production management technologies. FFStrained farmers outnumbered farmers trained via conventional extension approaches. The participation of stakeholders emerged after it was realized that most technologies developed by researchers alone were not appropriate for smallholder farmers.

The project in-charge provided a half-day orientation to the farmers regarding the project and presented the proposed content of the MOA. This activity ensured that all parties were aware of the necessary conditions to participate and remain in the dairy cattle project and helped farmers decide whether they should continue participating in the program. Thereafter, a tripartite MOA was signed by the barangay captain representing the barangay LGU, DA-Municipal LGU, and the University. In its research, Ha and Kim (2004) revealed that farmer organizations, where their members have 
Marcos E. Bollido, Teresa B. Polbos, Feleciano R. Bejar | ASEAN Journal of Community Engagement | Volume 4, Number 1, 2020

chances to generate income from sustainable dairy farming, raise awareness of business opportunities. Dolinska (2016) has been the conditions to assess the progress of an innovation project, considering farmers with mutual and positive information and preparation for negotiations. It is essential to use the opportunity to create dialogue collectively and assist farmers in creating new narratives. This view suggests that sharing power with farmers would help generate momentum during the innovation cycle.

The project succeeded because a strong partnership was established between the farmers and the DA, who initiated regular coaching and mentoring activities with the former. In this project, the barangay LGU-Animal Production Committee helped monitor the project to ensure that all local ordinances/policies and conditions were followed. The beneficiaries were given values formation training covering their love for their family, neighbors, environment, and God. Following this training, the farmerparticipants showed a positive outlook toward life, especially as regards livelihood improvements for their family, and expressed strong interest in earning money from the dairy cattle project.

Training on dairy cattle production was conducted to prepare the farmers for the project implementation. The 10 farmers began planting grasses and leguminous forages over a 500 sqm plot of idle land by adapting the legume strata technology. The effects of dairy production and breeding of livestock in smallholder farms have been illustrated in Bebe (2004) by a low level of feeding, which is linked to the restricted cash flow of households with weak resources. In general, livestock diets depend on poor bulk feed, even though households are substituting Bos indus for free-grazing by Bos taurus cattle for zero-grazing purposes.

The revenues from milk products like fresh milk, saw milk and butter generated, as reported by Kimaro, Mlangwa, Lyimo-Macha, \& Kimaro (2013), more income than other activities including the sales of vegetable products, local chickens, clothing sales and custom tailoring. Group membership was not an important factor in dairy farm income. Groups provided many advantages for the dairy sector, such as financing, training courses, dairy livestock acquisition and involvement in the agricultural activities at local and national level. For women dairy farmers, more training should be available on animal health management, market, and networking with a view to improving their income from dairy agriculture. In order to further its growth and sustainability, 
Marcos E. Bollido, Teresa B. Polbos, Feleciano R. Bejar | ASEAN Journal of Community Engagement | Volume 4, Number 1, 2020

women's groups should also obtain financial support from the local government, NGOs and other development partners.

While farmers developed their pasture area, the cows were subjected to artificial insemination (AI) and injected with hormones to synchronize heat which was given by the Department of Agriculture (DA) staff. The weight of the cattle increased from $150 \mathrm{~kg}$ at the beginning of the program to $300 \mathrm{~kg}$ upon distribution. Farmers managed their feeding scheme through a cut-and-carry strategy during bad weather and tethering during good weather. The 10 cows were impregnated through AI and gave calves. Milking was started shortly thereafter.

Muia et al. (2011) recorded the use of AI, extension and all-weather road facilities, by about 44 percent, 38 percent and 32 per cent of all households surveyed. Homes that house $59 \%$ cross breed dairy livestock while the other livestock contains $41 \%$ of pure dairy livestocks. The average livestock benefit per day was $322 \mathrm{~g}$, with milk production of $8.4 \mathrm{~kg}$ per cow. Weak road networks and milk marketing, high costs and inaccessibility of milk processing and support facilities, insufficient dairy production methods and minimal value addition of milk have been the major challenges in smallscale dairy production.

Gil et al. (2015), reports that combining crops, animals and/or forestry in the same region, also known as IS, will increase soil organic matter content that favors the production of biomass and allows higher livestock stocks in pastured areas. Therefore, IS implementation being a promising strategy for sustainable intensification of agriculture.

Odion et al. (2007) said that legumes should use nutrient from the depths of the soil profile and that at the beginning of the following growing cycle they should serve as green manure. Over-sowing legumes can be reduced, and the feed extracted from such plants can be included in the soil. The integrated legume forage has good liming effects, allowing soil acidity to be right, soil fertility improved, chemical fertilizer needs reduced and odorless weeds to be managed.

Evident ground-, deep-, and external-level impacts were observed in the community. The ground-level impact was that farmers were motivated to purchase additional ruminants and utilized up to 5 ha of idle land. Atuhaire et al. (2014) reported, although farmers have taken crop residues during times of feed shortage, to agro-industrial byproducts as a primary substitute feed supplemented with nature's pastures. 
Marcos E. Bollido, Teresa B. Polbos, Feleciano R. Bejar | ASEAN Journal of Community Engagement | Volume 4, Number 1, 2020

The deep-level impact was that the farmers developed a positive outlook toward venturing into ruminant production. Attitudinal transformations among family members, especially those of the five farmer-adopters of FLSST, were reported. Finally, as an external-level impact, nonparticipants of the project planted leguminous forages in their idle land and developed positive attitudes toward pasture development and dairy cattle production.

Luyombya (2014) recorded that $79.9 \%$ of qualified farmers were active in manual milking and dairy hygiene, $76.4 \%$ were pastures and food cropping's and $75.1 \%$ could adopt animal health practices. Also, 71.4 percent, 61.1 percent, 60.8 percent, 49.4 percent, respectively, took strong housing range, better breeds, feed and record keeping.

The research Rabbani et al (2004) of the Dairy Enterprise Participation study found that $65 \%$ of men, $19 \%$ of son, $10 \%$ of women, $1 \%$ of daughters and $4 \%$ of servants participated in feeding practices. Also, $78 \%$ of rural people milked their cows once a day, while $31 \%$ inseminated their cattle with artificial insemination. in the study areas. Participation in healthcare activities such as the use of disinfectants and utensils in their milk houses, vacuum use, treatment with the veterinary surgeon of their ill cow. The largest of the indigenous cattle reapers were smallholder farmers. The obstacle to milk production and the creation of dairy companies in the area were numerous problems. In order to increase milk production and the establishment of milk companies, improves feeding technology, a proper hygienic and sanitation programme, appropriate treatment, a sound breeding policy, and more participation in managerial practices are necessary.

Farm women are the leading players in small-scale agriculture, performing most important work. Although women play an important role in dairy farming, they have very limited controls over animals and their products. The profit of dairy animals is not in women's hands and the decision to sell and buy is also not made. Technology is required urgently, which will promote the work of respondents because they are very unpleasant, retroactive and monotonous and have an effect on their lifestyle and psychological health, druggery and physical activity. Women in farming should be inspired by various extension techniques to gain more scientific knowledge for increasing livestock production. (Rathod, Nikam, \& Landge, 2016). 
Marcos E. Bollido, Teresa B. Polbos, Feleciano R. Bejar | ASEAN Journal of Community Engagement | Volume 4, Number 1, 2020

The tropical forage legumes have great potential, aaccording to Schultze-Kraft et al. (2018), to improve the efficiency of forage-based livestock systems while adding environmental benefits. Positive soil conservation and soil chemical, physical and biodiversity benefits are the environmental benefits subsumed by 'ecosystem services;' water balance; prevention of global warming and pollution of groundwater; fossil energy savings; functional biodiversity; and land regeneration.

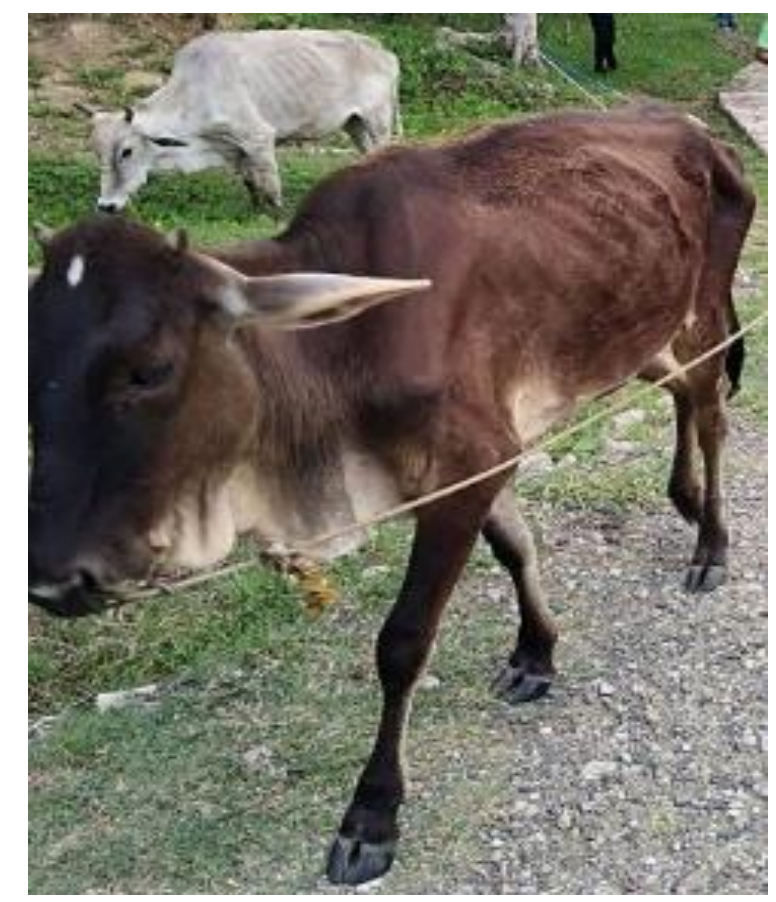

Fg. 2 Condition of the animal during their distribution Source: Authors (2019)

Figure 2 shows the appearance of the dairy cattle upon hand over to the farmerbeneficiaries. Standard procedures, such as weighing, deworming, and giving of vitamins, were carried out before the animals were released. The farmers were also given a take-home dewormer, vitamins, and forage plant materials. The condition of the animals revealed deficiencies in their care and management.

Most of the issues in cattle management involved the provision of an exact, sustainable, and nutritious supply of feeds. To address this problem, beneficiaries were asked to establish a forage plantation to feed their cattle prior to receiving the animals. 
Marcos E. Bollido, Teresa B. Polbos, Feleciano R. Bejar | ASEAN Journal of Community Engagement | Volume 4, Number 1, 2020

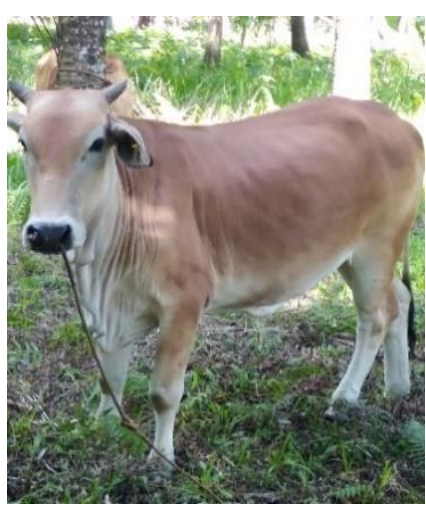

(a)

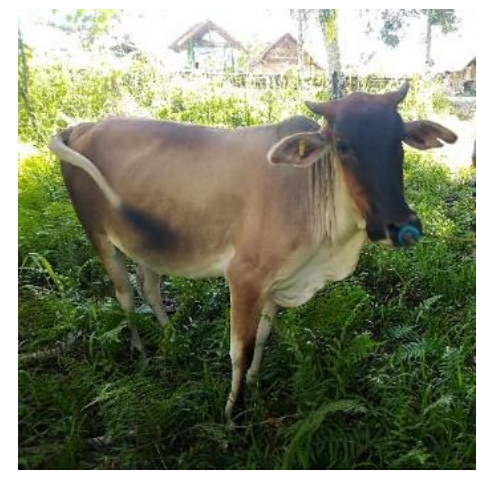

(b)

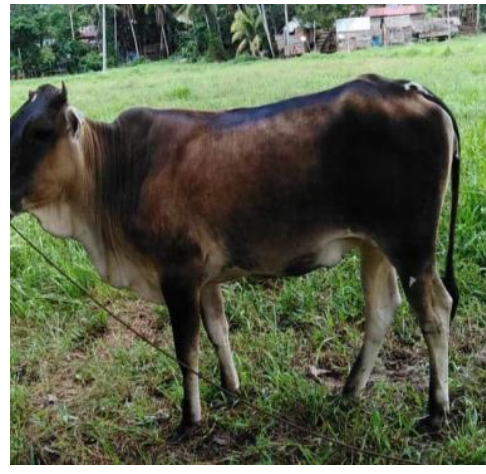

(c)

Fg. 3 (a); (b); and (c) Condition of animals 1 year after the project was implemented Source: Authors (2019)

Figure 3 shows the appearance of the dairy cattle more than 1 year after implementation of the project. The animals increased their weight by up to $50 \mathrm{~kg}$ and qualified for breeding. The animals were provided with abundant forages, regular deworming, and vitamins. The appearance of the animals confirmed how the beneficiaries fulfilled their roles and responsibilities in caring for their cattle.

The condition of the animals over 1 year after the management of the beneficiaries is tangible evidence that the beneficiaries planted forages to obtain an abundant source of nutritious feeds. The beneficiaries showed their sense of ownership of the project and involved all their family members in caring for their dairy cattle.

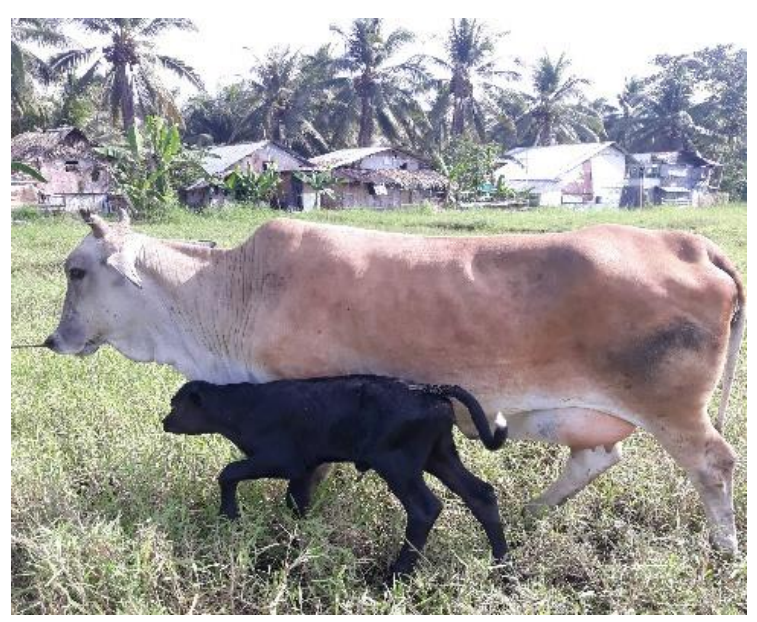

Fg. 4 Calf production

Source: Author (2019) 
Marcos E. Bollido, Teresa B. Polbos, Feleciano R. Bejar | ASEAN Journal of Community Engagement | Volume 4, Number 1, 2020

Figure 4 shows some of the cows that had produced calves after AI. Provision of a good source of feeds and appropriate care and management helped produce healthy and large calves during parturition. Because the beneficiaries had no bulls, they collaborated with the DA and National Dairy Authority (NDA) to receive technical assistance and actual coaching of estrus detection for effective AI. Beneficiaries obtained free semen from the NDA while dewormer and vitamins were obtained from the DA.

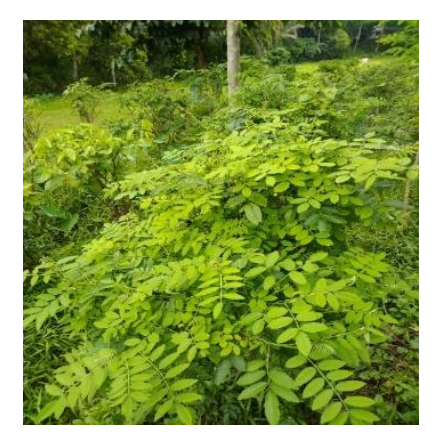

(a)

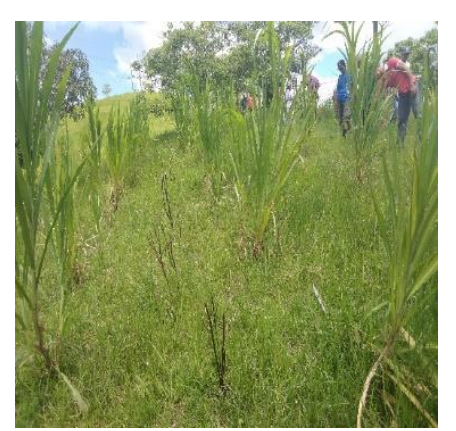

(b)

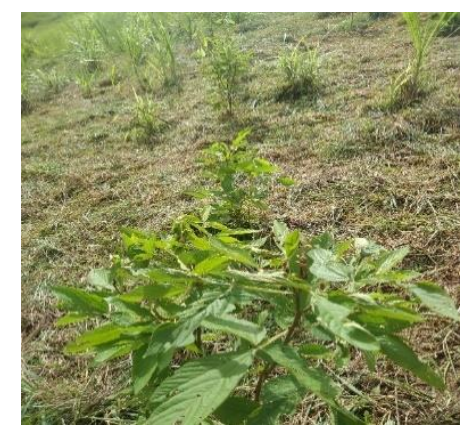

(c)

Fg. 5 (a); (b); and (c) Five hectares of idle land converted into pasture areas planted with superior Napier, humidicola, flemingia, indigofera, and stylo grass Source: Author (2019)

The farmer-beneficiaries (Figure 5) developed pasture areas planted with superior leguminous trees and grasses. Each farmer plated 500 sqm of pasture, which is adequate for their cow. Continuous planting was observed in preparation to produce cattle; small ruminants were also purchased. The development of pastures or plantation of forages was stipulated in the agreement and one of the vital requirements for the beneficiaries to avail of a dairy cow.

Aside from having the animals and forages, they were also molded of their values, while care and management of the cattle and pasture area was a must. To meet minimum requirements, the beneficiaries had to allocate a parcel of land and establish a 500 sqm forage plantation. The implementer provided the beneficiaries with planting materials and training on how to plant forages, which should comprise leguminous plants and grasses. The beneficiaries established their forage plantations within 3 months by adopting FLSST and were ready to sign the MOA and accept their dairy cow. 
Marcos E. Bollido, Teresa B. Polbos, Feleciano R. Bejar | ASEAN Journal of Community Engagement | Volume 4,

\section{Conclusion} Number 1, 2020

Farmers' development of pasture areas by planting with forages is a vital requirement in livestock production, especially that of ruminants. The progress of the dairy cattle project will depend on the awareness and understanding of livestock raisers about the importance of the establishment of pasture in the community. Leguminous forages can augment soil fertility via their nitrogen-fixing ability. The provision of dairy cattle boosted the interest of farmers in continuously planting leguminous forages in idle land to serve as cattle feeds. Idle (cogonal) lands planted with forages improved the production of small and large ruminants in Samar. Increasing cattle population in the area also improved the volume of milk produced. Supply of milk in the market will increase and eventually increase the income of the family derived from the sale of cow's milk. Values formation training changed the views of project beneficiaries on life, especially their love for their family and eagerness to manage the project to obtain a better income.

\section{Acknowledgement}

The author would like to extend heartfelt thanks to the farmers' participants who work voluntarily to develop the pasture area and devoted their time for the success of the project. My appreciation and thanks to Northwest Samar State University, Department of Agriculture Region 8 and the Local Government Unit of San Jorge who provided the financial and technical assistance in the implementation of the project. The support and encouragement of barangay captain from 5 barangays for our farmers to work hard for the successful project implementation.

\section{Author Contributions}

All authors conceptualized the idea of the project and this article. Marcos E. Bollido analyzed findings on the results of community intervention and monitored project activities, outcomes, and community impacts. Marcos E. Bollido and Teresa B. Polbos developed the substance theory of the article, verified the methods used, discussed the results, and contributed to the final manuscript. All authors contributed to the implementation of the project in the community and discussed the results and contributed to the final manuscript. 
Marcos E. Bollido, Teresa B. Polbos, Feleciano R. Bejar | ASEAN Journal of Community Engagement | Volume 4, Number 1, 2020

\section{References}

Atuhaire, A. M., Mugerwa, S., Kabirizi, J. M., Okello, S., \& Kabi, F. (2014). Production characteristics of smallholder dairy farming in the Lake Victoria Agro-ecological Zone Uganda. Frontiers in Science, 4(1), 12-19.

https://www.researchgate.net/publication/261641500_Production_Characteristics_ of_Smallholder_Dairy_Farming_in_the_Lake_Victoria_Agro-ecological_Zone_Uganda

Bebe, B. O. (2004). Effects of feeding systems and breed of cattle on reproductive performance and milk production on smallholder farms. Uganda Journal of Agricultural Sciences, 9(1), 558-563.

https://doi.org/10.14456/easr.2017.37

Bebe, B. O., Udob, H. M. J., \& Thorpe, W. (2003) Smallholder dairy systems in the Kenya highlands: feeding practices and production performances under increasing intensification. Herd Dynamics of Smallholder Dairy in the Kenya Highlands, 81. https://library.wur.nl/WebQuery/wurpubs/fulltext/121373\#page=81

Bosma, R. H., Roothaert, R. L., Asis, P., Saguinhon, J., Binh, L. H., \& Yen, V. H. (2003). Economic and social benefits of new forage technologies in Mindanao, Philippines, and Tuyen Quang, Vietnam. CIAT.

https://research.wur.nl/en/publications/economic-and-social-benefits-of-newforage-technologies-in-mindan

Cardona, C. A. C., Ramírez, J. F. N., Morales, A. M. T., Restrepo, E. M., Orozco, J. D. C., Vera, J. K., ... \& Rosales, R. B. (2014). Contribution of intensive silvopastoral systems to animal performance and to adaptation and mitigation of climate change. Revista Colombiana de Ciencias Pecuarias, 27(2), 76-94.

http://www.scielo.org.co/scielo.php?script=sci_abstract\&pid=S012006902014000200003

Devendra, C. (1997). Mixed farming and intensification of animal production systems in Asia. Outlook on Agriculture, 26(4), 255-265.

https://doi.org/10.1177/003072709702600407

Devendra, C. (2000). Animal production and rainfed agriculture in Asia: potential opportunities for productivity enhancement. Outlook on Agriculture, 29(3), 161-175. https://doi.org/10.5367/000000000101293202 
Marcos E. Bollido, Teresa B. Polbos, Feleciano R. Bejar | ASEAN Journal of Community Engagement | Volume 4, Number 1, 2020

Devendra, C., \& Chantalakhana, C. (2002). Animals, poor people, and food insecurity: opportunities for improved livelihoods through efficient natural resource management. Outlook on Agriculture, 3(13), 161-175.

https://doi.org/10.5367/000000002101294010

Dolinska, A., \& d'Aquino, P. (2016). Farmers as agents in innovation systems. Empowering farmers for innovation through communities of practice. Agricultural Systems, 142, 122-130.

https://doi.org/10.1016/j.agsy.2015.11.009

Ha, J. K., \& Kim, H. J. (2004). Management of dairy-animal feeding for better productivity and food safety. In Seminar on Sustainable Dairy-sector Development for Poverty Reduction, 22-27 November 2004 (pp. 25-35).

Hernández, I., \& Sánchez, M. D. (2014). Small ruminant management and feeding with high quality forages in the Caribbean. Santo Domingo, República Dominicana: IICA.

Hohnwald, S., Rischkowsky, B., Camarão, A. P., Schultze-Kraft, R., Rodrigues Filho, J. A., \& King, J. M. (2006). Integrating cattle into the slash-and-burn cycle on smallholdings in the Eastern Amazon, using grass-capoeira or grass-legume pastures. Agriculture, Ecosystems \& Environment, 117(4), 266-276.

https://doi.org/10.1016/j.agee.2006.04.014

German, L., Stroud, A., Amede, T., Opondo, C., \& Rao, S. (2006). Integrated Natural Resource Management in Practice: Enabling Communities to Improve Mountain Livelihoods and Landscapes.

http://hdl.handle.net/123456789/2528

Gil, J., Siebold, M., \& Berger, T. (2015). Adoption and development of integrated croplivestock-forestry systems in Mato Grosso, Brazil. Agriculture, Ecosystems \& Environment, 199, 394-406.

https://doi.org/10.1016/j.agee.2014.10.008

Kemp, D. R., \& Michalk, D. L. (2007). Towards sustainable grassland and livestock management. Journal of Agricultural Science-Cambridge, 145(6), 543. http://dx.doi.org/10.1017/S0021859607007253

Khan, M. J., Peters, K. J., \& Uddin, M. M. (2009). Feeding strategy for improving dairy cattle productivity in small holder farm in Bangladesh. Bangladesh Journal of Animal Science, 38(1-2), 67-85. 
Marcos E. Bollido, Teresa B. Polbos, Feleciano R. Bejar | ASEAN Journal of Community Engagement | Volume 4, Number 1, 2020

Kimaro, E. G., Mlangwa, J. E. D., Lyimo-Macha, J., \& Kimaro, J. G. (2013). The influence of women groups on income obtained from small-scale dairy cattle production: Acase of Arumeru District, Tanzania. Livestock Research for Rural Development, 25(4), 21-27. http://www.lrrd.org/lrrd25/4/kima25060.htm

Laidlaw, A. S., \& Teuber, N. (2001). Temperate forage grass-legume mixtures: advances and perspectives. International Grassland Congress, 19, 85-92. https://pdfs.semanticscholar.org/3f35/df8da6df39ffbc52a50f030dbf1f751772e5.pd f

Lamhauge, N., Lanzi, E., \& Agrawala, S. (2012). Monitoring and Evaluation for Adaptation: Lessons from Development Co-operation Agencies. OECD Environment Working Papers, 38. Paris: OECD Publishing. https://doi.org/10.1787/5kg20mj6c2bw-en

Lecture, H. S. M. (1997). Potential and prospects of legume-based pastures in the tropics. Tropical Grasslands, 31, 81-94.

http://www.tropicalgrasslands.info/public/journals/4/Historic/Tropical\%20Grassl ands\%20Journal\%20archive/PDFs/Vol_31_1997/Vol_31_02_97_pp81_94.pdf

Luyombya, B. G. P. (2014). Farmers' training and its influence on the adoption of improved dairy husbandry practices in Arumeru district (Doctoral dissertation, Sokoine University of Agriculture).

http://hdl.handle.net/123456789/464

Makori, J. A. (2007). Influence of farmer field school extension approach on smallholders' knowledge and skills of dairy management technologies in Molo Division, Nakuru District of Kenya (Doctoral dissertation, Egerton University).

Memorial, A. (2010). Ecological Intensification of Livestock Production Systems to Improve Livestock Productivity and Environmental Services on the Tugi (Gutah) Hills of the North West Region of Cameroon.

Muia, J. M. K., Kariuki, J. N., Mbugua, P. N., Gachuiri, C. K., Lukibisi, L. B., Ayako, W. O., \& Ngunjiri, W. V. (2011). Smallholder dairy production in high altitude Nyandarua milkshed in Kenya: Status, challenges, and opportunities. Livestock Research for Rural Development, 23(5), 2011.

https://www.researchgate.net/publication/290249543_Smallholder_dairy_producti on_in_high_altitude_Nyandarua_milk-

shed_in_Kenya_Status_challenges_and_opportunities 
Marcos E. Bollido, Teresa B. Polbos, Feleciano R. Bejar | ASEAN Journal of Community Engagement | Volume 4, Number 1, 2020

Muir, J. P., Pitman, W. D., Foster, J. L., \& Dubeux Jr, J. C. (2015). Sustainable intensification of cultivated pastures using multiple herbivore species. African Journal of Range \& Forage Science, 32(2), 97-112.

https://doi.org/10.2989/10220119.2015.1045555

Murgueitio, E., Calle, Z., Uribe, F., Calle, A., \& Solorio, B. (2011). Native trees and shrubs for the productive rehabilitation of tropical cattle ranching lands. Forest Ecology and Management, 261(10), 1654-1663.

https://doi.org/10.1016/j.foreco.2010.09.027

Odion, E. C., Asiribo, O. E., Ogunlela, V. B., Singh, B. B., \& Tarawali, S. A. (2007). Strategies to improve and sustain food production capacity in the savanna: The role of leguminous fodder crops in maintaining soil fertility and health. Journal of Food Agriculture and Environment, 5(2), 338.

https://www.researchgate.net/publication/267826827_Strategies_to_improve_and_ sustain_food_production_capacity_in_the_savanna_The_role_of_leguminous_fodder_cr ops_in_maintaining_soil_fertility_and_health

Rabbani, M. S., Alam, M. M., Ali, M. Y., Rahman, S. M. R., \& Saha, B. K. (2004). Participation of rural people in dairy enterprise in a selected area of Bangladesh. Pakistan Journal of Nutrition, 3(1), 29-34.

http://citeseerx.ist.psu.edu/viewdoc/download?doi=10.1.1.555.1711\&rep=rep1\&ty pe $=$ pdf

Rathod, P. K., Nikam, T. R., \& Landge, S. (2016). Participation of rural women in dairy farming in Karnataka. Indian Research Journal of Extension Education, 11(2), 31-36. https://mapn-ulm.ac.id/wp-content/uploads/2019/10/Participation-of-ruralwomen.pdf

Ridley, A. M., Mele, P. M., \& Beverly, C. R. (2004). Legume-based farming in Southern Australia: developing sustainable systems to meet environmental challenges. Soil Biology and Biochemistry, 36(8), 1213-1221.

https://doi.org/10.1016/j.soilbio.2004.04.007

Rossignoli, C., Di Iacovo, F. P., Moruzzo, R., \& Scarpellini, P. (2015). Dairy cattle, livelihoods and resilience in Gaza Strip: a case study. https://newmedit.iamb.it/share/img_new_medit_articoli/1006_24rossignoli.pdf 
Marcos E. Bollido, Teresa B. Polbos, Feleciano R. Bejar | ASEAN Journal of Community Engagement | Volume 4, Number 1, 2020

Rueda, B. L., McRoberts, K. C., Blake, R. W., Nicholson, C. F., Valentim, J. F., \& Fernandes,

E. C. M. (2020). Nutrient status of cattle grazing systems in the western Brazilian Amazon. Cogent Food \& Agriculture, 6(1), 1722350.

https://doi.org/10.1080/23311932.2020.1722350

Sarvade, S., Upadhyay, V. B., \& Agrawal, S. B. (2019). Quality fodder production through the silvopastoral system: a review. Agroforestry for Climate Resilience and Rural Livelihood, Eds: Inder Dev, Asha Ram, Naresh Kumar, Ramesh Singh, Dhiraj Kumar, AR Uthappa, AK Handa, \& OP Chaturvedi. Scientific Publishers. Jodhpur (Raj.). pp. 345-359.

Schultze-Kraft, R., Rao, I. M., Peters, M., Clements, R. J., Bai, C., \& Liu, G. (2018). Tropical forage legumes for environmental benefits: An overview. Tropical GrasslandsForrajes Tropicales, 6(1), 1-14.

http://dx.doi.org/10.17138/tgft

Stelzenmüller, V., Breen, P., Stamford, T., Thomsen, F., Badalamenti, F., Borja, Á., ... \& Degraer, S. (2013). Monitoring and evaluation of spatially managed areas: a generic framework for implementation of ecosystem based marine management and its application. Marine Policy, 37, 149-164.

https://doi.org/10.1016/j.marpol.2012.04.012

Uddin, M. N., Uddin, M. B., Al Mamun, M., Hassan, M. M., \& Khan, M. M. H. (2012). Small scale dairy farming for livelihoods of rural farmers: Constraint and prospect in Bangladesh. Journal of Animal Science Advances, 2(6), 543-550. https://www.academia.edu/download/31651226/JASA-2012-06-543-550.pdf

Valentim, J. F., \& Andrade, C. D. (2004). Perspectives of grass-legume pastures for sustainable animal production in the tropics. Reunião Annual Da Sociedade Brasileira De Zootecnia, 40, 142-154.

https://www.researchgate.net/publication/228417719_Perspectives_of_grasslegume_pastures_for_sustainable_animal_production_in_the_tropics

Waghorn, G. C., \& Clark, D. A. (2004). Feeding value of pastures for ruminants. New Zealand Veterinary Journal, 52(6), 320-331. 